\title{
Zachorowalność i umieralność u chorych na przewlekłą białaczkę limfocytową w Polsce w latach 1999-2013
}

\section{Morbidity and mortality of patients with chronic lymphocytic leukemia in Poland between 1999 and 2013}

Joanna Didkowska ${ }^{1}$, Urszula Wojciechowska ${ }^{1}$, Jakub Gierczyński ${ }^{2}$, Krzysztof Warzocha ${ }^{3}$, Ewa Lech-Marańda ${ }^{3,4}$

${ }^{1}$ Zakład Epidemiologii i Prewencji Nowotworów, Centrum Onkologii — Instytut im. M. Skłodowskiej-Curie, Warszawa ${ }^{2}$ Narodowy Instytut Zdrowia Publicznego — Państwowy Zakład Higieny, Warszawa

${ }^{3}$ Klinika Hematologii, Instytut Hematologii i Transfuzjologii, Warszawa

${ }^{4}$ Klinika Hematologii i Transfuzjologii, Centrum Medyczne Kształcenia Podyplomowego, Warszawa

\begin{abstract}
Streszczenie
Przewlekta biataczka limfocytowa (CLL) jest nowotworem, który sprawia pewne trudności w opisie epidemiologicznym ze względu na statystyczne ujęcie nowotworów krwi w X Rewizji Międzynarodowej Klasyfikacji Chorób i Problemów Zdrowotnych. W Polsce w 2013 roku CLL stanowita 1,3\% wszystkich zachorowań na nowotwory w populacji meżczyzn $i 1 \%$ u kobiet (odpowiednio 1,2\% i 0,9\% zgonów). Zapadalność wśród mężczyzn wynosita 3,3/100 tys., a wśród kobiet - 1,7 (umieralność odpowiednio 1,8/100 tys. $i$ 0,7/100 tys.). Mediana wieku zachorowania na CLL $w$ Polsce to 69 lat. Wskaźniki 5-letnich przeżyć względnych wśród pacjentów zdiagnozowanych $w$ latach 2006-2009 wynosity 55,8\% wśród mężczyzn i 68,1\% wśród kobiet.
\end{abstract}

Słowa kluczowe: zachorowalność, umieralność, przewlekła białaczka limfocytowa

Hematologia 2016; 7, 2: 108-116

\begin{abstract}
Chronic lymphocytic leukemia (CLL) is a cancer that is epidemiologically difficult to describe arising from the definition of the blood cancers adopted in the 10th Revision of the International Statistical Classification of Diseases and Related Health Problems. In Poland CLL cases accounted for $1.3 \%$ and $1 \%$ in men and 1 women respectively in 2013 (1.2\% and $0.9 \%$ of deaths). The incidence for men was 3.3/100,000 and 1.7/100,000 in women (mortality rates being 1.8/100,000 and 0.7/100,000 respectively). In Poland, the median patient's age is 69 years. Indicators of 5-year relative survival for patients diagnosed in 2006-2009 were 55.8\% for men and $68.1 \%$ for women.
\end{abstract} Key words: incidence, mortality, chronic lymphocytic leukemia

Hematologia 2016; 7, 2: 108-116 
Tabela 1. Liczba zachorowań, współczynnik surowy (wsp. surowy) i standaryzowany (wsp. stand.) zachorowalności na przewlekłą białaczkę limfocytową w Polsce w latach 1999-2013 według danych Krajowego Rejestru Nowotworów

Table 1. Number of chronic lymphocytic leukemia cases crude (wsp. surowy) and standarised (wsp. stand.) morbidity rates of chronic lymphocytic leukemia in Poland during 1999-2013, according to the National Cancer Registry

\begin{tabular}{|l|c|c|c|c|c|c|c|c|c|}
\hline \multirow{2}{*}{ Rok } & \multicolumn{3}{|c|}{ Mężczyźni } & \multicolumn{3}{c|}{ Kobiety } & \multicolumn{3}{c|}{ Ogółem } \\
\cline { 2 - 11 } & Liczba & $\begin{array}{c}\text { Wsp. } \\
\text { surowy }\end{array}$ & $\begin{array}{c}\text { Wsp. } \\
\text { stand. }\end{array}$ & Liczba & $\begin{array}{c}\text { Wsp. } \\
\text { surowy }\end{array}$ & $\begin{array}{c}\text { Wsp. } \\
\text { stand. }\end{array}$ & Liczba & $\begin{array}{c}\text { Wsp. } \\
\text { surowy }\end{array}$ & $\begin{array}{c}\text { Wsp. } \\
\text { stand. }\end{array}$ \\
\hline 1999 & 402 & 2,1 & 1,7 & 380 & 1,9 & 1,1 & 782 & 2,0 & 1,4 \\
\hline 2000 & 510 & 2,7 & 2,1 & 426 & 2,1 & 1,2 & 936 & 2,4 & 1,6 \\
\hline 2001 & 516 & 2,7 & 2,1 & 400 & 2,0 & 1,1 & 916 & 2,4 & 1,6 \\
\hline 2002 & 547 & 3,0 & 2,2 & 434 & 2,2 & 1,2 & 981 & 2,6 & 1,6 \\
\hline 2003 & 630 & 3,4 & 2,5 & 425 & 2,2 & 1,2 & 1055 & 2,8 & 1,7 \\
\hline 2004 & 658 & 3,6 & 2,6 & 484 & 2,5 & 1,3 & 1142 & 3,0 & 1,8 \\
\hline 2005 & 631 & 3,4 & 2,5 & 495 & 2,5 & 1,3 & 1126 & 3,0 & 1,8 \\
\hline 2006 & 665 & 3,6 & 2,5 & 507 & 2,6 & 1,3 & 1172 & 3,1 & 1,8 \\
\hline 2007 & 671 & 3,6 & 2,5 & 540 & 2,7 & 1,4 & 1211 & 3,2 & 1,9 \\
\hline 2008 & 755 & 4,1 & 2,8 & 581 & 2,9 & 1,4 & 1336 & 3,5 & 2,0 \\
\hline 2009 & 864 & 4,7 & 3,1 & 605 & 3,1 & 1,5 & 1469 & 3,9 & 2,2 \\
\hline 2010 & 705 & 3,8 & 2,5 & 567 & 2,9 & 1,3 & 1272 & 3,3 & 1,8 \\
\hline 2011 & 741 & 4,0 & 2,6 & 493 & 2,5 & 1,1 & 1234 & 3,2 & 1,8 \\
\hline 2012 & 731 & 3,9 & 2,4 & 526 & 2,6 & 1,2 & 1257 & 3,3 & 1,7 \\
\hline 2013 & 992 & 5,3 & 3,3 & 757 & 3,8 & 1,7 & 1749 & 4,5 & 2,4 \\
\hline
\end{tabular}

\section{Wprowadzenie}

Przewlekła białaczka limfocytowa (CLL, chronic lymphocytic leukemia) jest nowotworem, który sprawia pewne trudności $\mathrm{w}$ opisie epidemiologicznym ze względu na specyfikę X Rewizji Międzynarodowej Klasyfikacji Chorób i Problemów Zdrowotnych (ICD-10, International Statistical Classification of Diseases and Related Health Problems 10th Revision). Przewlekła białaczka limfocytowa powinna być kodowana kodem szczegółowym C91.1 (przewlekła białaczka limfocytowa) i taka jest praktyka Krajowego Rejestru Nowotworów (KRN). $Z$ kolei kodowanie prowadzone przez koderów Głównego Urzędu Statystycznego (GUS), służące prowadzeniu statystyki zgonów (na podstawie kart zgonu), nierzadko ogranicza się do kodu szczegółowego C91.9 (białaczka limfatyczna nieokreślona — ok. 20\% wszystkich kodów C91 na początku okresu obserwacji, spadek do $10 \%$ w ostatniej dekadzie obserwacji), co wynika $z$ ograniczonej informacji wpisanej przez lekarza wystawiającego kartę zgonu. Należy jednocześnie podkreślić, że ICD-10 jest klasyfikacją służącą celom głównie statystycznym, a nie medycznym.

W pracy przedstawiono analizę zachorowań na CLL i zgonów osób chorujących na ten nowotwór w Polsce w latach 1999-2013. Analiza została przeprowadzona na podstawie danych pochodzących $z$ dwóch baz danych, tj. KRN i GUS, oraz posłużono się współczynnikami standaryzowanymi według populacji świata [1]. Przeprowadzono również, metodą Hakulinena, analizę przeżyć chorych na CLL $[2,3]$.

\section{Zachorowalność na przewlekłą białaczkę limfocytową}

W 2013 roku spośród zgłoszeń nowych przypadków nowotworów do KRN zgłoszenia CLL stanowiły $1,3 \%$ wszystkich zachorowań na nowotwory w populacji mężczyzn i $1 \%$ zachorowań w populacji kobiet. Liczba zachorowań na CLL w latach 1999-2013 wzrosła ponad 2-krotnie - 782 zachorowania w 1999 roku w porównaniu z 1749 zachorowaniami w 2013 roku, przy czym zjawisko to było silniej zaznaczone w populacji mężczyzn (tab. 1). W Polsce CLL (ICD-10: C91.1) jest najczęstszym typem spośród białaczek limfatycznych (ICD-10: C91) i w 2013 roku stanowiła prawie 80\% zachorowań na wszystkie białaczki limfocytowe u obu płci (ryc. 1). Wśród wszystkich zachorowań na białaczki (C91-C95) CLL (C91.1) stanowiła około $48 \%$ zachorowań (ryc. 2). 


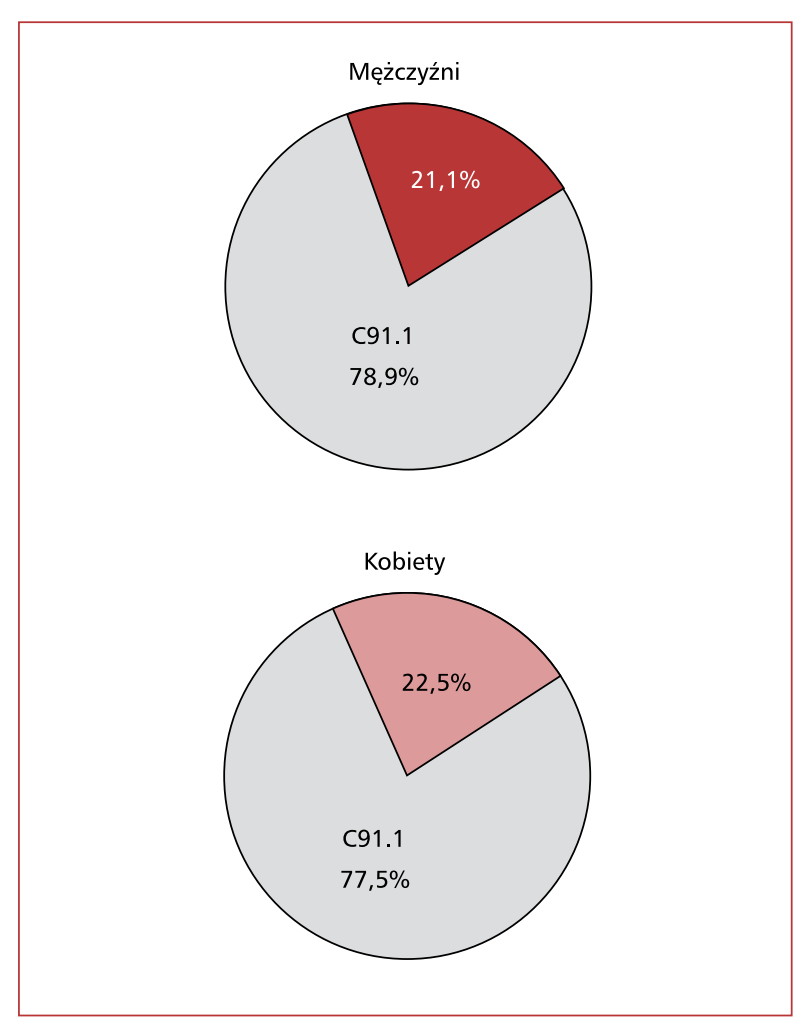

Rycina 1. Udział zachorowań na przewlekłą białaczkę limfocytową (ICD-10: C91.1) w innych białaczkach limfatycznych (ICD-10: C91) w Polsce w 2013 roku na podstawie danych Krajowego Rejestru Nowotworów

Figure 1. Number of chronic lymphocytic leukemia cases (ICD-10: C91.1) within other lymphatic leukemias (ICD-10: C91) in Poland according to the National Cancer Registry data for 2013

Dla porównania w Niemczech, gdzie każdego roku odnotowuje się 5000 nowych zachorowań na CLL (3000 nowych przypadków u mężczyzn i 2000 u kobiet), stanowi ona przyczynę $1,1 \%$ wszystkich zachorowań na nowotwory u mężczyzn i $0,8 \%$ zachorowań na nowotwory u kobiet oraz $41,8 \%$ wszystkich zachorowań na białaczki (C91-C95) u mężczyzn i 37,2\% u kobiet [4]. W Wielkiej Brytanii w 2013 roku przy 3442 nowych rozpoznaniach CLL, w tym 2164 (63\%) u mężczyzn i 1278 (37\%) u kobiet [5], udział CLL wynosił $1 \%$ nowych przypadków zachorowań na nowotwory ogółem oraz stanowił $37 \%$ wszystkich nowych rozpoznań z zakresu białaczek ogólem (C91-C95) w 2013 roku [5]. Według estymacji American Cancer Society w Stanach Zjednoczonych zostanie odnotowanych 18960 nowych przypadków CLL w 2016 roku [6]. Na podstawie danych za lata 2010-2012 szacuje się, że w Stanach Zjednoczonych życiowe ryzyko zachorowania wynosiło $\mathrm{w}$ całej populacji około $0,6 \%$
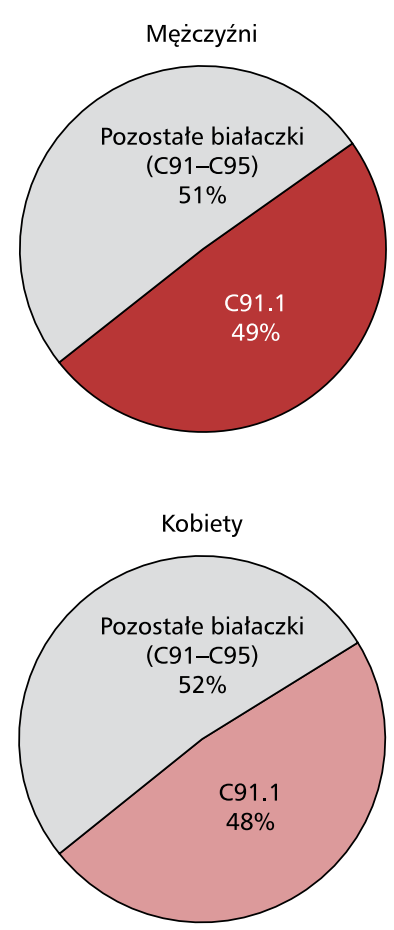

Rycina 2. Udział zachorowań na przewlekłą białaczkę limfocytową (ICD-10: C91.1) w innych białaczkach (ICD10: C91-C95) w Polsce w 2013 roku na podstawie danych Krajowego Rejestru Nowotworów

Figure 2. Number of chronic lymphocytic leukemia cases (ICD-10: C91.1) within other leukemias (ICD-10: C91-C95) in Poland according to the National Cancer Registry data for 2013

[6]; w Polsce w tym samym okresie ryzyko życiowe zachorowania na CLL według KRN wynosiło $0,4 \%$. Na tle 60140 nowych zachorowań na wszystkie białaczki (C91-C95) w Stanach Zjednoczonych CLL będzie stanowić 31,53\% [6].

Przewlekła białaczka limfocytowa występuje przede wszystkim u osób dorosłych, a mediana wieku zachorowania w Polsce wynosi 69 lat (68 lat u mężczyzn i 71 lat u kobiet). Dla porównania w 2011 roku w Niemczech mediana w chwili rozpoznania CLL wyniosła 72 lata u mężczyzn i 75 lat u kobiet [5], a w Stanach Zjednoczonych wynosiła 64-70 lat [7].

Według danych KRN jedynie około $10 \%$ zachorowań obserwuje się przed 50. rokiem życia. Najwięcej zachorowań u mężczyzn występuje w Polsce między 60. a 79. rokiem życia, w przypadku kobiet natomiast między 65 . a 84. rokiem życia. Stwierdza się wzrost współczynnika zachorowalności wraz z przechodzeniem do starszych grup 


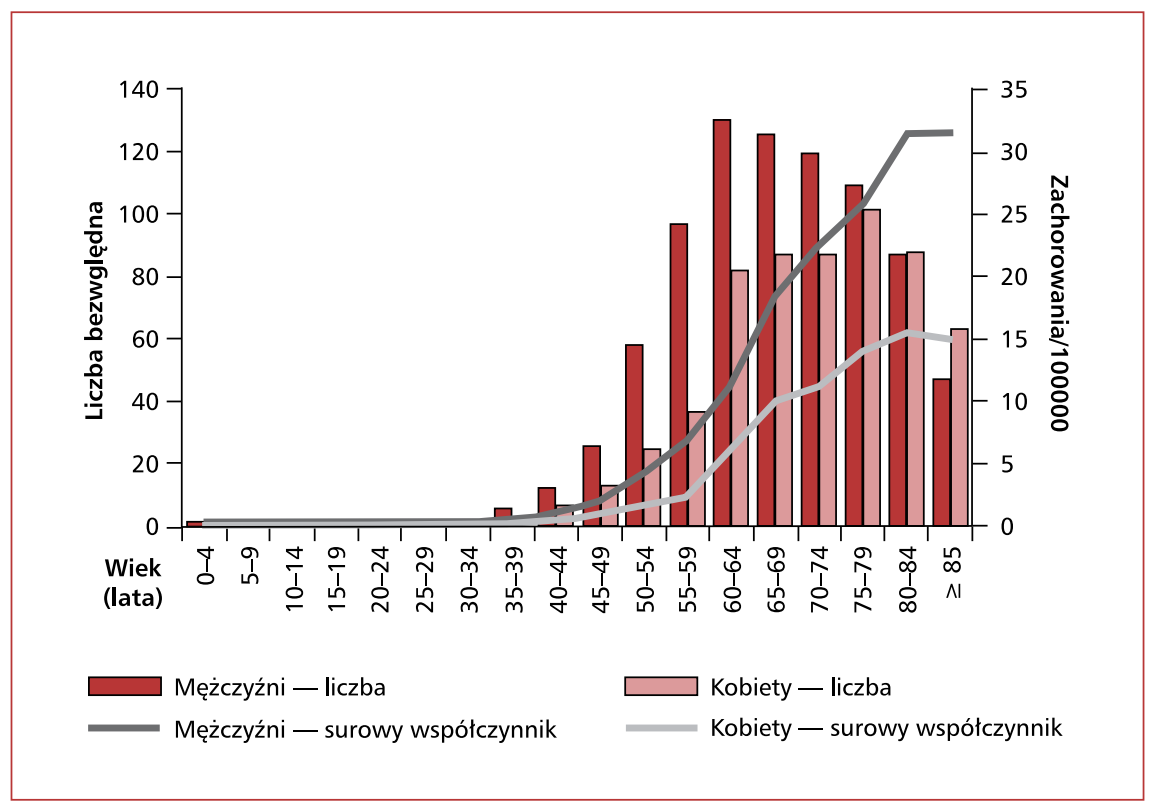

Rycina 3. Zachorowalność na przewlekłą białaczkę limfocytową w zależności od wieku w Polsce w latach 2011-2013 według danych Krajowego Rejestru Nowotworów

Figure 3. Morbidity rates by age for chronic lymphocytic leukemia during 2011-2013 in Poland according to the National Cancer Registry data

wiekowych, który w 9. dekadzie życia osiąga wartość około 32/100 tys. u mężczyzn i 15/100 tys. u kobiet. Współczynniki zachorowalności na CLL są 2-krotnie wyższe u mężczyzn we wszystkich grupach wiekowych. Liczba zachorowań jest większa u mężczyzn niż u kobiet w przedziałach wiekowych do 79. roku życia, w przedziale wiekowym 80-84 lata jest podobna u obu płci, natomiast po 85, roku życia jest większa wśród kobiet (ryc. 3).

W obserwowanym okresie zachorowalność na CLL charakteryzuje rosnący trend w populacji mężczyzn i kobiet (ryc. 4). Wartość współczynnika zachorowalności w tym przedziale czasu wzrosła o ponad $150 \%$ u obu płci, osiągając u mężczyzn $3,3 / 100$ tys., a u kobiet $1,7 / 100$ tys. Zwiększenie zachorowalności obserwuje się również we wszystkich grupach wiekowych (ryc. 5). Tempo wzrostu zachorowalności mężczyzn w grupach wiekowych jest wyższe niż kobiet.

Dla porównania w Wielkiej Brytanii współczynnik zachorowalności wyniósł 7,0/100 tys. u mężczyzn i 4,0/100 tys. w przypadku kobiet [5], w Niemczech 4,9/ 100 tys. wśród mężczyzn i 2,5/100 tys. u kobiet [4], natomiast w Czechach w 2007 roku - 6,2/100 tys. łącznie u obu płci [9]. W Stanach Zjednoczonych współczynnik ten w odniesieniu do obu płci kształtował się na poziomie 4,6/100 tys. populacji [6].

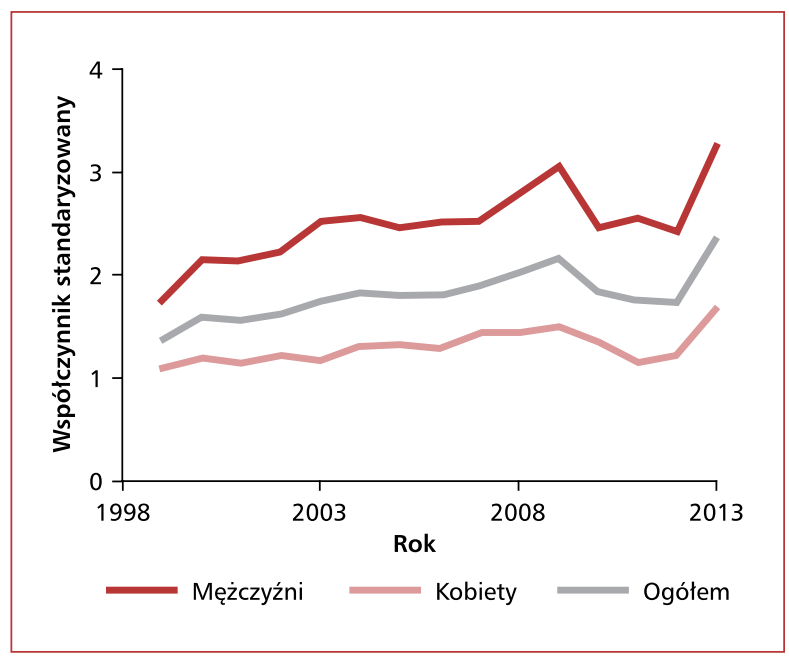

Rycina 4. Trendy zachorowalności na przewlekłą białaczkę limfocytową w Polsce w latach 1999-2013 na podstawie danych Krajowego Rejestru Nowotworów

Figure 4. Morbidity rate trends for chronic lymphocytic leukemia in Poland during 1999-2013 according to the National Cancer Registry data

\section{Umieralność w przebiegu CLL}

W 2013 roku w Polsce zgony chorych na CLL stanowiły 1,2\% zgonów nowotworowych mężczyzn 


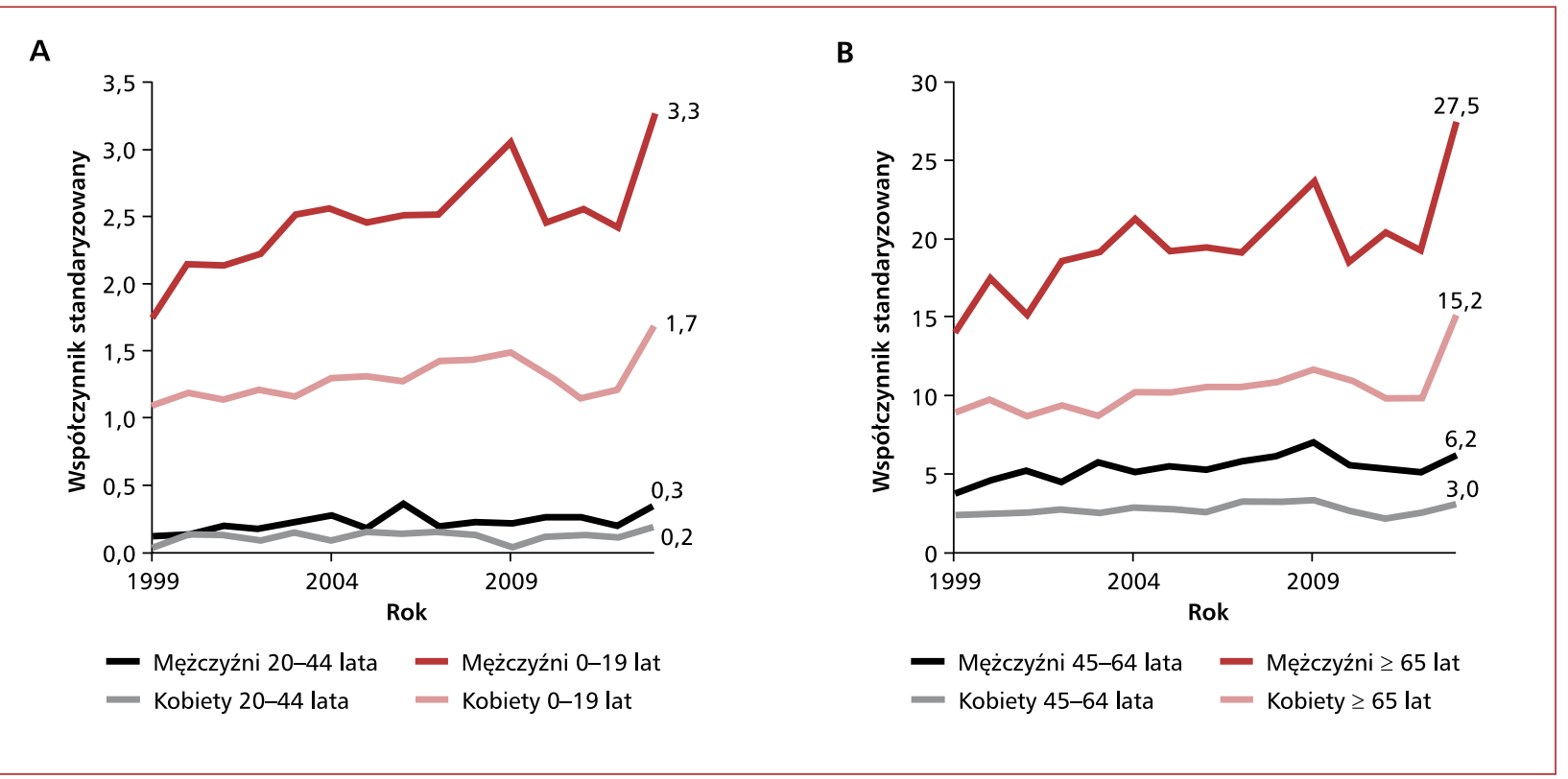

Rycina 5 A, B. Trendy zachorowalności na przewlekłą białaczkę limfocytową w wybranych grupach wiekowych w Polsce w latach 1999-2013 na podstawie danych Krajowego Rejestru Nowotworów

Figure 5 A, B. Morbidity rate trends for chronic lymphocytic leukemia age groups in Poland during 1999-2013 according to the National Cancer Registry data

Tabela 2. Liczba zgonów, współczynnik surowy (wsp. surowy) i standaryzowany (wsp. stand.) umieralności na przewlekłą białaczkę limfocytową w Polsce w latach 1999-2013 na podstawie danych Krajowego Rejestru Nowotworów

Table 2. Number of chronic lymphocytic leukemia deaths, crude (wsp. surowy) and standarised (wsp. stand.) mortality rates of chronic lymphocytic leukemia in Poland during 1999-2013, according to the National Cancer Registry data

\begin{tabular}{|l|c|c|c|c|c|c|c|c|c|}
\hline \multirow{2}{*}{ Rok } & \multicolumn{3}{|c|}{ Mężczyźni } & \multicolumn{3}{c|}{ Kobiety } & \multicolumn{3}{c|}{ Ogółem } \\
\cline { 2 - 10 } & Liczba & $\begin{array}{c}\text { Wsp. } \\
\text { surowy }\end{array}$ & $\begin{array}{c}\text { Wsp. } \\
\text { stand. }\end{array}$ & Liczba & $\begin{array}{c}\text { Wsp. } \\
\text { surowy }\end{array}$ & $\begin{array}{c}\text { Wsp. } \\
\text { stand. }\end{array}$ & Liczba & $\begin{array}{c}\text { Wsp. } \\
\text { surowy }\end{array}$ & $\begin{array}{c}\text { Wsp. } \\
\text { stand. }\end{array}$ \\
\hline 1999 & 299 & 1,6 & 1,3 & 217 & 1,1 & 0,6 & 545 & 1,4 & 0,9 \\
\hline 2000 & 328 & 1,7 & 1,4 & 263 & 1,3 & 0,7 & 619 & 1,6 & 1,0 \\
\hline 2001 & 356 & 1,9 & 1,4 & 242 & 1,2 & 0,6 & 607 & 1,6 & 1,0 \\
\hline 2002 & 365 & 2,0 & 1,5 & 290 & 1,5 & 0,7 & 690 & 1,8 & 1,1 \\
\hline 2003 & 400 & 2,2 & 1,6 & 248 & 1,3 & 0,6 & 636 & 1,7 & 0,9 \\
\hline 2004 & 388 & 2,1 & 1,4 & 279 & 1,4 & 0,6 & 691 & 1,8 & 1,0 \\
\hline 2005 & 412 & 2,2 & 1,6 & 304 & 1,5 & 0,7 & 756 & 2,0 & 1,1 \\
\hline 2006 & 452 & 2,5 & 1,6 & 333 & 1,7 & 0,7 & 760 & 2,0 & 1,0 \\
\hline 2007 & 427 & 2,3 & 1,5 & 351 & 1,8 & 0,7 & 830 & 2,2 & 1,1 \\
\hline 2008 & 479 & 2,6 & 1,6 & 382 & 1,9 & 0,8 & 875 & 2,3 & 1,2 \\
\hline 2009 & 493 & 2,7 & 1,7 & 362 & 1,8 & 0,7 & 861 & 2,2 & 1,1 \\
\hline 2010 & 499 & 2,7 & 1,7 & 355 & 1,8 & 0,7 & 893 & 2,3 & 1,1 \\
\hline 2011 & 538 & 2,9 & 1,8 & 413 & 2,1 & 0,8 & 937 & 2,4 & 1,1 \\
\hline 2012 & 524 & 2,8 & 1,6 & 384 & 1,9 & 0,7 & 988 & 2,6 & 1,2 \\
\hline 2013 & 604 & 3,2 & 1,8 & 400 & 2,0 & 0,7 & 1004 & 2,6 & 1,2 \\
\hline
\end{tabular}




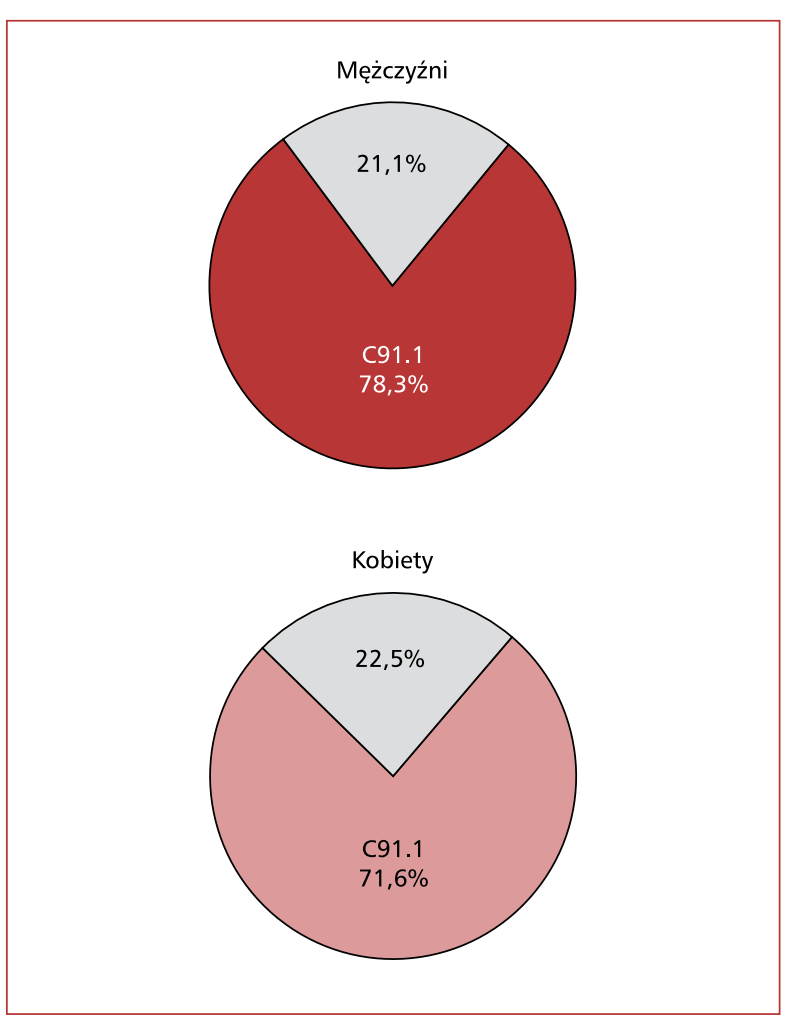

Rycina 6. Udział zgonów na przewlekłą białaczkę limfocytową (ICD-10: C91.1) w innych białaczkach limfatycznych (ICD-10: C91) w Polsce w 2013 roku na podstawie danych Głównego Urzędu Statystycznego

Figure 6. Number of chronic lymphocytic leukemia cases (ICD-10: C91.1) within other lymphatic leukemias (ICD-10: C91) in Poland according to the Central Statistical Office data for 2013

i 0,9\% zgonów na nowotwory wśród kobiet. Liczba zgonów z powodu CLL w latach 1999-2013 wzrosła blisko 2-krotnie w populacji mężczyzn z 299 zgonów w 1999 roku do 604 zgonów w 2013 roku, a wśród kobiet, odpowiednio, z 217 do 400 przypadków zgonów (tab. 2). W 2013 roku zgony spowodowane CLL stanowily około $77 \%$ zgonów z powodu białaczek limfatycznych ogółem (ICD-10: C91.0-C91.9) oraz 36\% wśród wszystkich typów białaczek (C91-C95) (ryc. 6, ryc. 7).

W Niemczech w 2011 roku z powodu CLL zmarło 1000 mężczyzn i 850 kobiet [4]. W Stanach Zjednoczonych estymacja oparta na latach 2009-2013 wskazuje w 2016 roku liczbę zgonów $z$ powodu CLL na poziomie 4660, co stanowi $19,1 \%$ wszystkich zgonów z powodu białaczek ogółem (24 400; C91-C95). Oszacowane współczynniki zgonów z powodu CLL to $1,3 / 100$ tys. populacji ogółem [8].

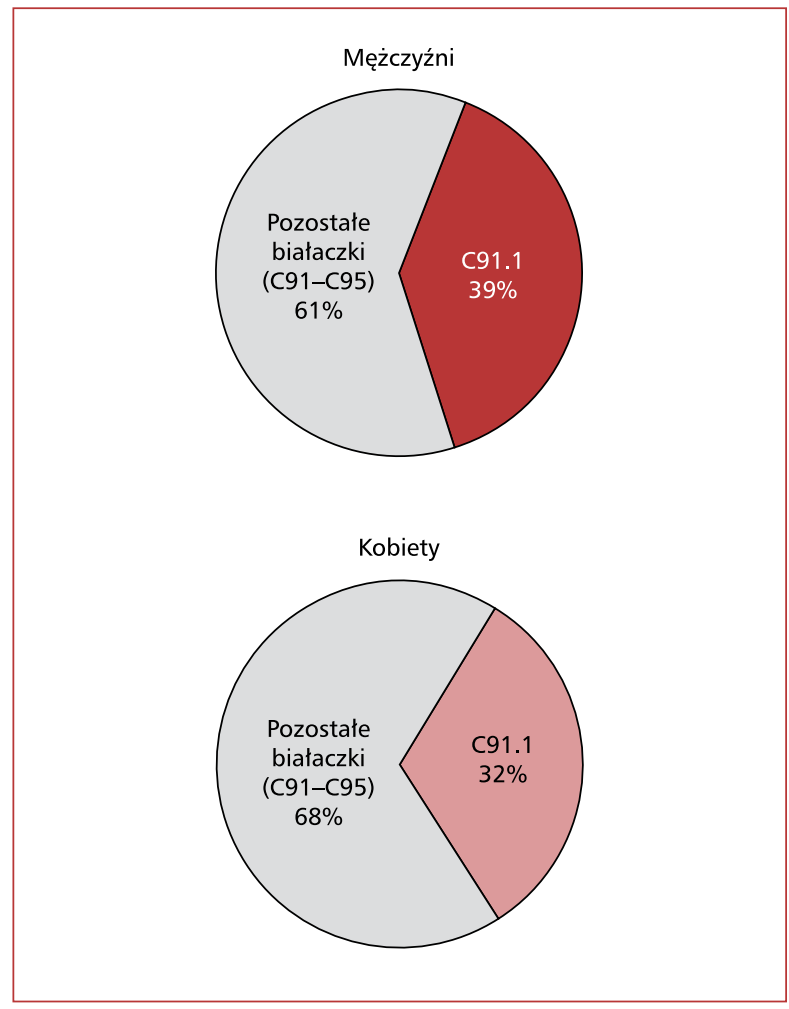

Rycina 7. Udział zgonów na przewlekłą białaczkę limfocytową (ICD-10: C91.1) w innych białaczkach (ICD-10: C91-C95) w Polsce w 2013 roku na podstawie danych Głównego Urzędu Statystycznego

Figure 7. Number of chronic lymphocytic leukemia deaths (ICD-10: C91.1) within other leukemias (ICD-10: C91-C95) in Poland according to the Central Statistical Office data for 2013

Według danych KRN liczba zgonów z powodu CLL wzrasta $z$ wiekiem u obu płci. Zgony przed 50. rokiem życia występują bardzo rzadko. Umieralność zwiększa się $z$ wiekiem, osiągając najwyższe wartości w najstarszych grupach wiekowych (ryc. 8). Znacząco wyższą umieralność obserwuje się u mężczyzn w porównaniu $z$ kobietami we wszystkich grupach wiekowych przed 80. rokiem życia.

Umieralność mężczyzn $z$ powodu CLL wzrastała w Polsce w obserwowanym okresie $z$ 1,3/ /100 tys. w 1999 roku do 1,8/100 tys. w 2013 roku. Trend umieralności kobiet w latach 1999-2013 nie wykazywał znaczących zmian i wartość standaryzowanego współczynnika umieralności wynosiła 0,6-0,8/100 tys. populacji kobiet (ryc. 9). Wśród osób w średnim wieku umieralność pozostawała na stałym poziomie u obu płci, natomiast u osób powyżej 65. roku życia obserwowano jej wzrost u obu płci, przy czym wyraźnie większy u mężczyzn (ryc. 10). 
Hematologia 2016, tom 7, nr 2

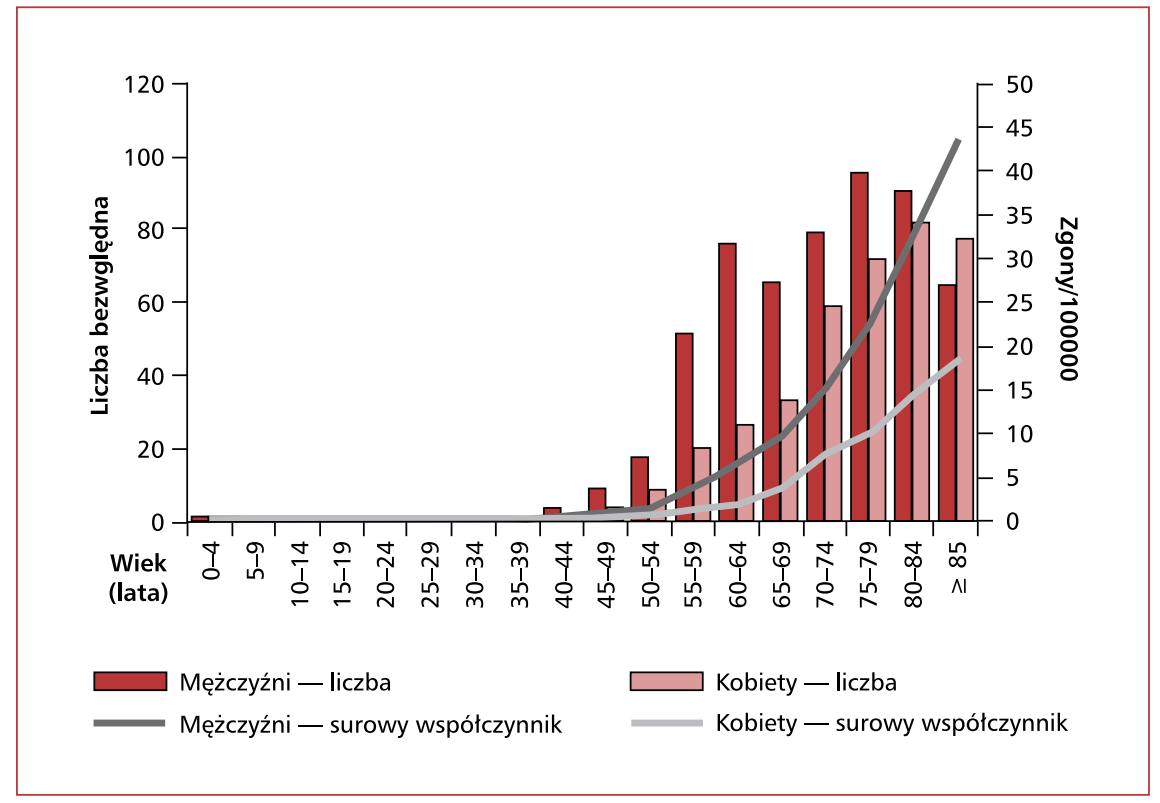

Rycina 8. Umieralność chorych na przewlekłą białaczkę limfocytową w zależności od wieku w Polsce w latach 2011-2013 na podstawie danych Głównego Urzędu Statystycznego

Figure 8. Mortality rates by age of patients with for chronic lymphocytic leukemia during 2011-2013 in Poland according to the Central Statistical Office data

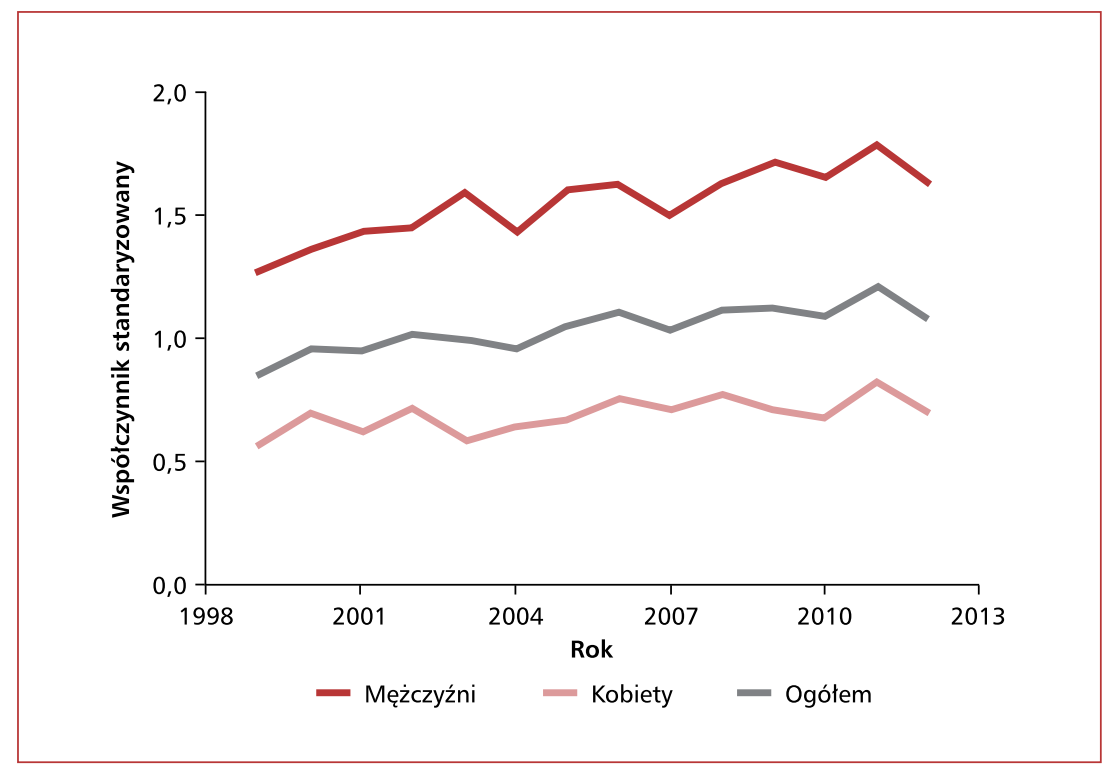

Rycina 9. Trendy umieralności na przewlekłą białaczkę limfocytową w Polsce w latach 1999-2013 na podstawie danych Głównego Urzędu Statystycznego

Figure 9. Mortality rate trends for chronic lymphocytic leukemia in Poland during 1999-2013 according to the Central Statistical Office data 


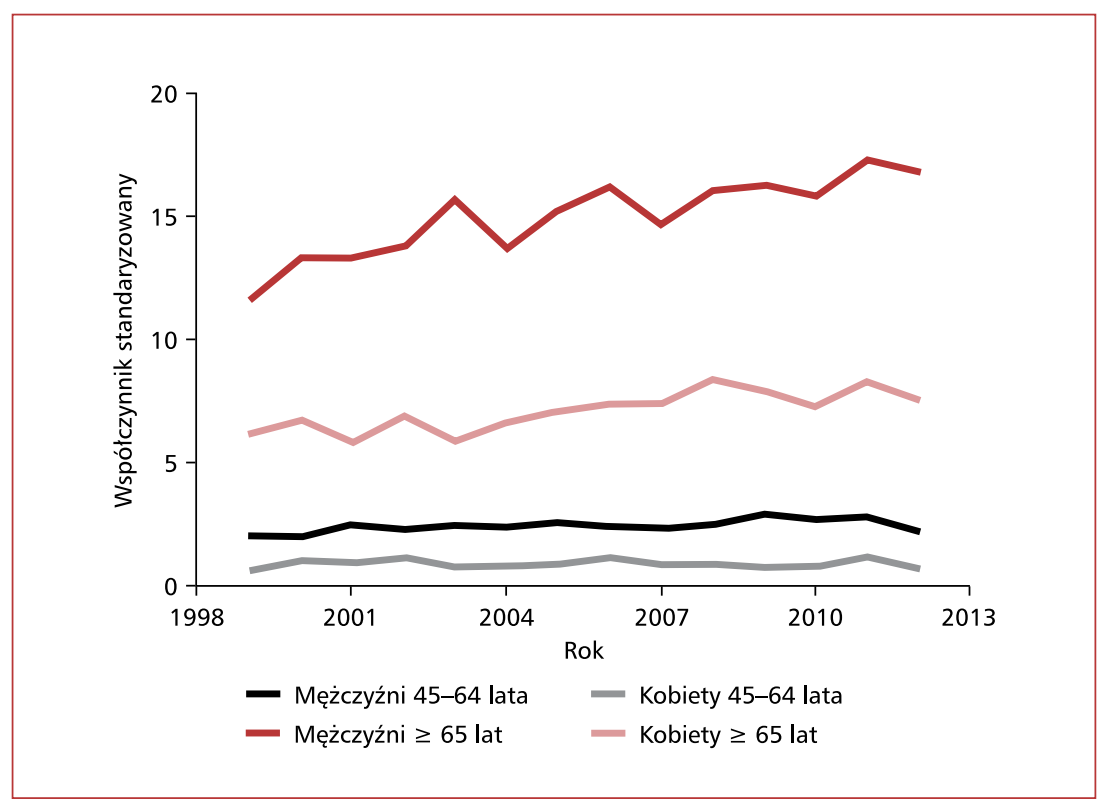

Rycina 10. Trendy umieralności na przewlekłą białaczkę limfocytową w wybranych grupach wiekowych w Polsce w latach 1999-2013 na podstawie danych Głównego Urzędu Statystycznego

Figure 10. Mortality rate trends for chronic lymphocytic leukemia age groups in Poland during 1999-2013 according to the Central Statistical Office data

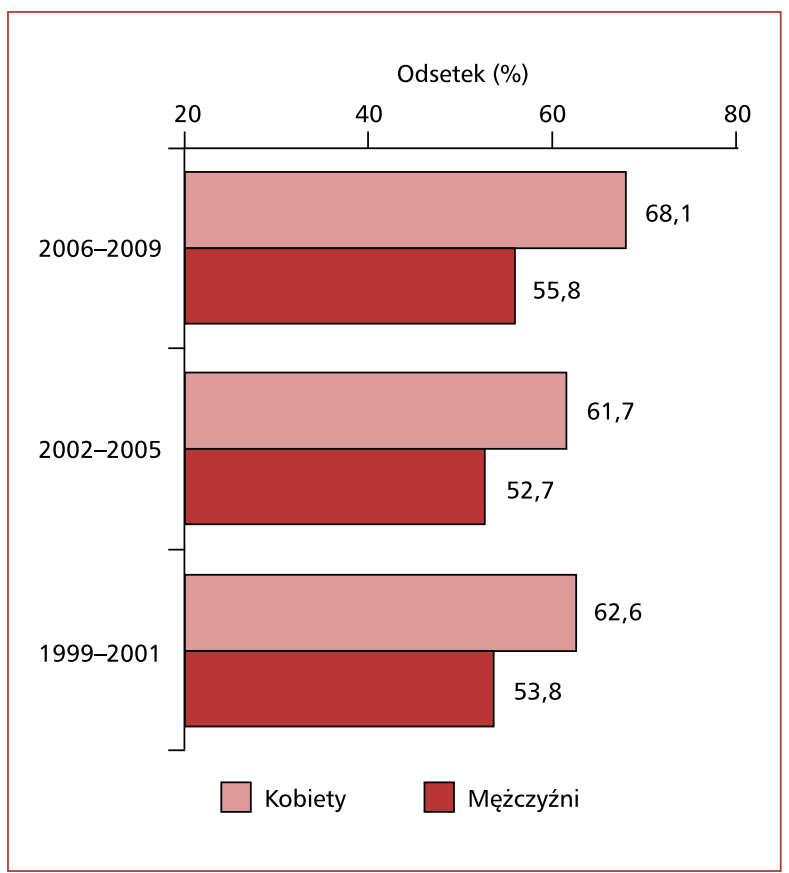

Rycina 11. Standaryzowane względne wskaźniki przeżyć 5-letnich chorych na przewlekłą białaczkę limfocytową (91.1) w Polsce w latach 1999-2009 na podstawie danych Krajowego Rejestru Nowotworów

Figure 11. Standarised relative indicators/ratios of 5 year survival rates of patients with chronic lymphocytic leukemia (91.1) in Poland during 1999-2013 according to the National Cancer Registry data

\section{Wskaźniki przeżyć chorych na CLL}

Standaryzowane względne wskaźniki 5-letnich przeżyć chorych na CLL w pierwszej dekadzie XXI wieku znacząco się poprawiły, w szczególności wśród kobiet. Wskaźniki te u kobiet chorych na CLL wzrosły o ponad 5 punktów procentowych (p.p.), w latach 2006-2009, osiągając wartość $68,1 \%$. W analogicznym przedziale czasowym u mężczyzn obserwowano wzrost o 2 p.p. i wśród chorych diagnozowanych w latach 2006-2009 wskaźnik ten wynosił 55,8\%. Różnica wskaźników przeżyć między płciami wzrosła z 9 p.p. w latach 1999-2001 i 2002-2005 do ponad 12 p.p. w latach 2006-2009 (ryc. 11).

W Stanach Zjednoczonych 5-letnie przeżycie względne u pacjentów zdiagnozowanych w latach 2006-2012 oszacowano na 82,6\% zarówno u mężczyzn, jak i u kobiet [8]. W Wielkiej Brytanii 5-letnie wskaźniki przeżyć względnych wynoszą $70 \%$ u mężczyzn i 75\% u kobiet [5].

W największym europejskim badaniu, w którym porównywano przeżycia chorych na nowotwory hematologiczne, wykazano wzrost 5-letnich wskaźników przeżyć chorych na CLL w ciągu dekady między końcem ubiegłego wieku (1997-1999) a początkiem XXI wieku (2006-2008) z 66,1\% $(65,1-67,1)$ do $69,0 \%(68,1-69,8)(\mathrm{p}<0,0001)$ [9]. 
Autorzy badania podkreślają, że tylko nieznaczny wzrost przeżywalności obserwowano w południowej Europie, natomiast w krajach Europy Północnej, Środkowej i Wschodniej dokonał się znaczny postęp. Nadal jednak w krajach wschodnioeuropejskich przeżycia były krótsze niż w innych regionach Europy, a Polskę od średniej europejskiej dzieli około 15 p.p. $(53,04 \%$ v. $69,58 \%)$.

\section{Podsumowanie}

W pracy po raz pierwszy przedstawiono dane dotyczące epidemiologii CLL w Polsce; zakres analizy obejmował lata 1999-2013. W większości rejestrów nowotworowych publikuje się łączne dane odnoszące się do wszystkich białaczek (C91-C95), dlatego trudno ocenić, czy około 2-krotnie niższa częstość występowania CLL w Polsce, w porównaniu ze Stanami Zjednoczonymi czy Wielkiej Brytanii, jest również charakterystyczna dla innych krajów naszego regionu. Jednocześnie w literaturze tematu częstość występowania CLL została oszacowana na znacznie niższym poziomie - w Stanach Zjednoczonych (populacja rasy kaukaskiej) na 3,4-3,7/100 tys. mężczyzn i 1,6-1,9/100 tys. kobiet; w Europie 2,2-3,4 u mężczyzn i 1,6-1,9 u kobiet; w Oceanii, odpowiednio, 2,8-3,0 i 1,4-1,5 [10]. Na tym tle zachorowalność w Polsce utrzymuje się na poziomie obserwowanym w Europie (3,3 u mężczyzn i 1,7 u kobiet). Podobne trudności związane $z$ niedostatkiem publikowanych danych napotkano przy próbie porównania populacyjnych wskaźników przeżyć. $Z$ wyjątkiem projektu Eurocare tylko w nielicznych rejestrach (projekt SEER, Wielka Brytania) publikuje się szczegółowe dane dotyczące CLL, natomiast dane w literaturze przedmiotu odnoszą się do tak zwanego przeżycia całkowitego, które reprezentuje wyselekcjonowane grupy chorych.

\section{Piśmiennictwo}

1. Didkowska J., Wojciechowska U. Nowotwory złośliwe w Polsce w 2013 roku. Centrum Onkologii — Instytut im. M. Skłodowskiej-Curie, Warszawa 2015.

2. Hakulinen T. Cancer survival corrected for heterogeneity in patient withdrawal. Biometrics 1982; 38: 933-942.

3. Corazziari I., Quinn M., Capocaccia R. Standard cancer patient population for age standardising survival ratios. Eur J Cancer. 2004; 40: 2307-2316.

4. Association of Population-based Cancer Registries in Germany (GEKID) Dostępne na: http://www.gekid.de/index_e.html. Data dostępu: 7.04.2016 r.

5. Chronic lymphocytic leukaemia (CLL) statistics. Cancer Research UK. Dostępne na: http://www.cancerresearchuk.org/health-professional/cancer-statistics/statistics-by-cancer-type/leukaemiacll. Data dostępu: 30.04.2016 r.

6. What are the key statistics for chronic lymphocytic leukemia? American Cancer Society's Cancer Statistics Center. Dostępne na: http://www.cancer.org/cancer/leukemia-chroniclymphocyticcll/detailedguide/leukemia-chronic-lymphocytic-key-statistics. Data dostępu: 30.04.2016 r.

7. Redaelli A., Laskin B., Stephens J.M., Botteman M.F., Pashos C.L. The clinical and epidemiological burden of chronic lymphocytic leukaemia. Eur. J. Cancer Care (Engl.) 2004; 13: 279-287.

8. SEER Stat Fact Sheets: Chronic Lymphocytic Leukemia (CLL). Surveillance, Epidemiology, and End Results (SEER) Program of the National Cancer Institute (NCI). Dostępne na: http://seer. cancer.gov/statfacts/html/clyl.html. Data dostępu: 30.04.2016 r.

9. Sant M., Minicozzi P., Mounier M. i wsp. Survival for haematological malignancies in Europe between 1997 and 2008 by region and age: results of EUROCARE-5, a population-based study. Lancet Oncol. 2014; 15: 931-942.

10. Panovská A., Doubek M., Brychtová Y., Mayer J. Chronic lymphocytic leukemia and focusing on epidemiology and management in everyday hematologic practice: recent data from the Czech Leukemia Study Group for Life (CELL). Clin. Lymphoma Myeloma Leuk. 2010; 10: 297-300. 